\title{
EFABULAÇÕES HOMOERÓTICAS: ANTÓNIO NOBRE RELIDO NA FICÇÃO DE MÁRIO CLÁUDIO
}

Jorge Vicente Valentim (UFSCar/CAPES/UP)

Resumo: Pretende-se, neste ensaio, apresentar uma leitura do conto "António Nobre e Alberto de Oliveira" (da coletânea Triunfo do amor português, 2004), do escritor português Mário Cláudio, sublinhando como eixo demarcador da efabulação a relação homoerótica das duas personagens principais. Dos seus primeiros contatos, na Universidade de Coimbra, ao compartilhamento do espaço doméstico comum, em Leça da Palmeira, até à separação fatídica, depois de um desentendimento em Paris, toda a trajetória aparece assinalada pela impossibilidade da concretização amorosa. Revisitando o século XIX português, procuraremos assinalar como Mário Cláudio lança mão de recursos caros a uma poética do pós-modernismo para recompor uma relação homoafetiva que marcou as letras portuguesas no fin-desiécle oitocentista.

Palavras-chave: Homoerotism, Século XIX, Mário Cláudio, Ficção portuguesa contemporânea.

Abtract: We intend in this essay to presente a reading of the story "António Nobre e Alberto de Oliveira" (from Triunfo do amor português, 2004), by the Portuguese writer Mário Cláudio, stressing as path axis of the fictional construction the homoerotic relationship of the two main characters From their first contacts at the University of Coimbra, to the sharing of common domestic space, in Leça da Palmeira, until the fateful separation, after a misunderstanding in Paris, the entire trajectory appears marked by the impossibility of loving achievement. Revisiting the Portuguese nineteenth century, Mário Cláudio tries to point out expensive resorts to a poetics of postmodernism to recompose an homoafective relationship that marked the Portuguese scene in the nineteenth fin-de-siècle.

Key-words: Homoerotism, XIXth Century, Mário Cláudio, Contemporary Portuguese Fiction. 
Tudo é biografia, digo eu. Tudo é autobiografia, digo com mais razão ainda, eu que a procuro (a autobiografia? a razão?). Em tudo ela se introduz (qual?), como uma delgadíssima lâmina metida na fenda da porta e que faz saltar o trinco, devassando a casa. José Saramago. Manual de pintura e caligrafia.

Nos estudos críticos da pós-modernidade, já é um consenso observar a presença intercambiante de gêneros textuais, ora numa troca declarada e explícita, ora num diálogo intertextual, por vezes escamoteado nas malhas discursivas. A ideia de um imbricado jogo intertextual entre categorias pouco convencionais e já consagradas pela tradição, que "atravessa a fronteira de gêneros sem fazer restrições" (HUTCHEON, 1991, p. 181) ou impor hierarquias condicionalizantes entre prática e teoria, entre um tipo de texto mais importante que outro, aparece sublinhada entre os mais diferentes teóricos da pós-modernidade, sugerindo o trânsito genológico como uma das ênfases mais pontuais desta estética.

Por outro lado, como bem relembra Ana Paula Arnaut, a novidade não se encontra exatamente nesta fluidez genológica, onde subgêneros, há pouco tempo impensados dentro de um discurso crítico, aparecem de maneira explícita e não superficial, ou, ainda,

a recorrente e crescente utilização e aglutinação de maior diversidade de géneros ou, ainda, a tendência 
para, pela presença mais ou menos ostensiva e mais ou menos equilibrada de traços característicos dessas diferentes tipologias, implodir e esbater os contornos das fronteiras intergenológicas, e, com isso, dificultar a inserção da obra explicitamente em um ou em outro género (2002, p. 142)

A novidade reside, portanto, na maneira como todo este fluxo intercambiante se realiza, fazendo implodir o texto, afastando-o, assim, de uma pretensa categorização fixa. Ou seja, a possibilidade de trânsito entre diferentes categorias acentua a sua multiplicidade e exacerba esta flexibilização das fronteiras classificadoras, privilegiando exatamente aquilo que destas escapa e faz questão de assim se mostrar. Afinal, como bem lembra Linda Hutcheon, não é "o múltiplo, o heterogêneo, o diferente" (1991, p. 95), a grande tônica da "retórica pluralizante do pós-modernismo" (HUTCHEOM, 1991, p.95)? Não é possível detectar uma constância na minagem e no consequente comprometimento das bases dos "clichés genológicos, como subvertendo, contrariando e violando preceitos básicos" (ARNAUT, 2002, p. 142), corroendo os "próprios universos de representação" (ARNAUT, 2002, p. 142)?

Por isso, nas análises propostas pela crítica da produção mais recente na literatura portuguesa, esta diversidade de gêneros, esta fluidez na sua consecução, este exacerbado 
trânsito genológico compareçam quase que de maneira sistemática e unânime (ARNAUT, 2002; REAL, 2012; REIS, 2005; ROCHA, 2002; SEIXO, 2001). Não será gratuita, portanto, a lúcida conclusão de Ana Paula Arnaut, ao afirmar, sobre o Post-modernismo no romance português contemporâneo: "O que fundamentalmente muda, pois, é o tipo e o modo de transgressão" (2002, p. 142).

Dentre os tipos e os modos de transgressão deste processo de mútua transitoriedade genológica, a questão biográfica constitui um dos avatares das reflexões pós-modernas. Isto porque a ideia de biografia parece estar não apenas ligada à questão dos instrumentos utilizados para a classificação (ou será rotulação?) de um tipo de texto, mas também vincada à suposição de uma historicidade, seja ela puramente do objeto eleito para a escrita, seja ela essencialmente voltada a um enquadramento epocal e coletivo. Daí a explicação de Arnaldo Momigliano, ao entender as múltiplas relações de interferência entre os dois polos discursivos:

de nos jours, personne, sans doute, ne conteste que la biographie soit une catégorie de l'histoire. II vaudrait mieux remonter à ceux qui inventèrent la biographie, les anciens Grecs, et se demander porquoi eux n'ont jamais admis que la biographie relevait de l'histoire (1971, p. 17). 
Ou seja, fortemente ligada ao discurso histórico, a biografia não deixa de desenvolver alguns laços com este outro gênero, no sentido, inclusive de manter-se fiel a uma certa recuperação temporal linear não apenas do sujeito alvo da criação textual, mas também do contexto epocal em que ele se encontra inserido. Esta, por exemplo, é também a concepção desenvolvida por Carlos Reis e Ana Cristina M. Lopes no seu Dicionário de Narratologia. Segundo os autores,

a biografia constitui a representação, muitas vezes em forma de relato, da vida de uma determinada personalidade, no desenrolar da sua existência, no seu crescimento e maturação, nos eventos que lhe deram peculiaridade e mesmo nos incidentes que conduziram ao desaparecimento dessa personalidade. (1987, p. 46)

Ratificada, portanto, como uma categoria narrativa, a biografia pode encaminhar-se para duas modalidades: a analítica, quando existe uma preocupação ensaística e de interpretação do(s) objeto(s) eleitos como alvo discursivo, e a narrativa, alicerçada sobretudo na "dinâmica da história de uma vida" (REIS; LOPES, 1987, p. 46), sem abrir mão de recursos essencialmente narrativos para a sua composição. Vale lembrar, neste último caso, que "o respeito pela temporalidade eventualmente reelaborada pelo discurso" 
(REIS; LOPES, 1987, p. 46) é um dos traços específicos deste tipo de texto. Daí, talvez, o fato de Vergílio Ferreira, quando de sua leitura do romance Amadeo, de Mário Cláudio, observar neste título a inferência de um romance histórico, na mesma tonalidade de $O$ ano da morte de Ricardo Reis, de José Saramago.

No entanto, não me parece que a preocupação do ensaísta português tenha sido exatamente sublinhar o romance de Mário Cláudio como uma espécie narrativa da mesma natureza dos romances do século XIX, ainda que, inevitavelmente, neles tenha esbarrado para ponderar sobre as principais linhas de força da ficção portuguesa contemporânea. Parece-me que a preocupação maior de Vergílio Ferreira tenha sido a de observar o fundo da obra em questão (Amadeo) como algo que ultrapassa a própria condição de categorização do romance, posto que não se trataria de ler apenas a vida de um artista numa sequência linear ou de um tempo em que as novidades da vanguarda marcaram profundamente um momento da cultura portuguesa, mas de reconhecer a "inscrição do destino do homem na História" (FERREIRA, 1987, p. 132). Mais preocupado em sublinhar as continuidades, os afastamentos e as heranças deixadas pelas gerações de Orpheu, da presença e do neorrealismo na 
ficção contemporânea, Vergílio Ferreira não terá medo em concluir categoricamente que a grande lição da intromissão da história narrativa será a de se constituir

a expressão, entre muitas coisas, da desindividualização do nosso tempo, da sua condição problemática, do desvio da atenção do que aos nossos olhos se processa, por nada de forte e de absorvente e de unificador se oferecer (1987, p. 132).

Ora, diante desta compreensão da inferência da narrativa histórica, do seu apontamento para uma dissolução das pretensas seguridades vinculadas nas sociedades contemporâneas, da "condição problemática" de se apreender uma história que não pode mais ser fundamentada na concepção hegeliana de causa e consequência, de uma linearidade sujeita a cesuras e fraturas, de uma categoria ficcional que se preocupa em fixar o destino do homem, com tudo aquilo que possui de precário, de provisório e de contingente, não podemos concordar com a aplicação que faz Maria Ângela Azevedo Furtado-Brum (1997) sobre estas considerações de Vergílio Ferreira, achando que o autor de Espaço do invisível IV estaria rotulando o romance de Mário Cláudio dentro das mesmas prerrogativas do gênero cultivado no século XIX. É claro que, sensível e culto nas suas 
reflexões, Vergílio Ferreira conhecia bem o tema tratado (o romance histórico), por isso, reconhece, em última instância, que as relações estabelecidas entre história e ficção promovem explicações mais atuais e condizentes com o contexto contemporâneo, dentre as quais o autor sublinha a "dissolução ou suspensão do nosso tempo" (1987, p. 132).

Neste sentido, a proposta de leitura de Vergílio Ferreira estaria, de certa forma, em consonância com a "biografia romanceada", dentro dos moldes definidos por Reis e Lopes:

Fala-se de biografia romanceada quando, em primeiro lugar, a biografia não se exime a excursos de natureza ficcional: o mundo actual do biografado pode então fazer-se um mundo possível, interligando-se eventos e personagens factualmente verificáveis com eventos e personagens inteiramente ficcionais, naquilo que se designa como "modalidade mista de existência". Para além disso, a biografia romanceada recorre a técnicas de caracterização da personagem, de tratamento do tempo, de ilustração de espaços, etc., consolidadas pela tradição romanesca propriamente dita; deste modo a biografia acaba por ser tributária do legado de subgéneros como o romance de educação, o roman fleuve, o romance histórico, etc. (1987, p. 47)

Ser tributário do romance histórico, por lançar mão de recursos semelhantes (construção de mundos possíveis, 
ligação de situações referenciais com outras de caráter puramente ficcional, caracterizações de personagens, tempos e espaços), não significa, portanto, que sejam gêneros idênticos. Os laços estreitam-se entre eles muito mais em virtude dos instrumentos de criação utilizados do que propriamente pela matéria de referencialidade por vezes comprovada. O próprio Mário Cláudio, em entrevista a Joaquim Matos, ao explicar os recursos utilizados para a construção de Rosa, deixa clara a consonância existente entre o tipo de texto que pretende criar com a biografia romanceada, nos termos acima definidos. Nas palavras do autor de Guilhermina,

De facto, o que acontece é que se realmente eu procurasse traçar o percurso de uma personagem em termos de uma cronologia, em termos de efemérides ligadas à sua vida, eu estaria a fazer uma biografia, que é aquilo que não me interessa fazer. Estou interessado, realmente, em construir um trabalho de ficção, que também seja uma biografia, mas não uma biografia de sujeito, exclusivamente, mas também daquilo a que poderíamos chamar a sua circunstância, portanto, do sujeito, do espaço em que ele está integrado, da atmosfera em que ele vive e sobretudo das pessoas que a habitam, uma biografia da memória. Não é por acaso que hoje, por exemplo, em França, alguns autores utilizam a palavra psicobiografia, que adopto sem relutância para os trabalhos 
que vou fazendo. Portanto, são também psicobiografias, se tivermos em conta, por outro lado, que uma psicobiografia não é apenas a biografia do indivíduo, mas também a biografia do colectivo. Temos a lição de Jung, que é uma lição de grande fecundidade para nos mostrar que não somos exclusivamente aquilo que somos, individualmente, mas muito mais do que isso. Portanto, quando falo, não falo de uma pessoa só, falo de muitas, quando falo de uma, falo de muitos espaços, quando falo de um, falo de muitas épocas, quando falo de uma. (Apud MATOS, 2004, p. 76-77)

Depreende-se, portanto, que a proposta original de Mário Cláudio não se coaduna com os procedimentos padrões e canônicos da escrita biográfica tradicional. Ou seja, a sua preocupação aproxima-se mais daquilo que Reis e Lopes (1987) definiram como biografia romanceada do que da biografia analítica ou da narrativa, em virtude dos mundos possíveis construídos, das situações experienciadas, dos espaços e dos tempos recuperados pela memória nos bordados ficcionais, a partir das experiências artísticas e das trajetórias de vida de Amadeo de Souza-Cardoso, Guilhermina Suggia e Rosa Ramalha, figuras tutelares do cenário cultural português, transformadas em personagens protagonistas na sua Trilogia da Mão. 
Se esta espécie de biografia romanceada levada a termo por Mário Cláudio ensaia e coteja alguns pontos de contato com uma história cultural portuguesa, sem perder de vista os encadeamentos contextuais e coletivos com as diferentes pessoas, épocas e situações temporais, conforme clarificado na entrevista acima citada, também não se pode generalizar que tais textos se situem num enquadramento fiel ao gênero celebrado por Linda Hutcheon como o grande avatar da poética do pós-modernismo: a metaficção historiográfica.

Definida como um gênero textual que incorpora dois polos aparentemente distantes (o ficcional e o fatual), a metaficção historiográfica possui uma "autoconsciência teórica sobre a história e a ficção como criações humanas" (HUTCHEON, 1991, p. 22) capaz de anular a provável separação entre eles. Compreendendo o acesso ao passado histórico pela textualidade, a metaficção historiográfica incide numa reflexão contínua sobre a "natureza discursiva de todas as referências - literárias e historiográficas" (HUTCHEON, 1991, p. 158). Daí a preocupação de Hutcheon em frisar que não se trata exclusivamente de um romance histórico, nos moldes já reconhecidos pela tradição, porque ela constitui um gênero que se debruça sobre o factual, enquanto objeto textual, da mesma forma como se inclina sobre o ficcional e o entende 
como um constructo humano. Nos dois casos, reúne-os através de sua matéria discursiva, revelando paulatinamente os mecanismos textuais empregados na sua criação. Texto que se debruça sobre o texto e sobre os mecanismos de como ele é feito, sem perder a consciência das distintas naturezas e das origens de onde suas fontes provêm.

Por isso, ao falar de biografia romanceada, de texto ficcional que recupera uma vida, uma trajetória, um tempo, um espaço, enfim, um contexto histórico-cultural, sem se desvencilhar das questões político-sociais que envolvem tais aspectos, em alguns casos, pode-se também inferir que esta categoria tem pontos de convergência com a metaficção historiográfica, sobretudo nela se percebem algumas artimanhas narrativas, tais como o desdobramento das vozes autorais e narrantes, que vão sendo gradativamente encenadas e descobertas no tecido ficcional. No entanto, nunca é demais repetir que toda a generalização é perigosa. Há de observar-se, nesta perspectiva, que o fato de um escritor como Mário Cláudio valer-se desta espécie textual em obras como Guilhermina (CERDEIRA, 2000) ou As batalhas do Caia (ARNAUT, 2000), não quer dizer necessariamente que, ao investir sobre outras trajetórias biográficas com uma proposta e um projeto de escrita 
muito próximo daqueles, a mesma categoria possa ser útil como protocolo de leitura.

Aqui vale a pena frisar que a aposta de Mário Cláudio incide sobre reconhecidas figuras do cenário artístico português, sobretudo na trajetória de poetas e de pintores, dando-Ihes toda uma coloração homoafetiva. Do universo das artes plásticas, o romancista português recupera o nome de Amadeo de Souza-Cardoso, iminente pintor da geração de Orpheu, em Amadeo (1984), primeiro romance da Trilogia da mão, e com o qual recebeu o Grande Prémio de Romance e Novela da APE, no mesmo ano. E do contexto literário, Mário Cláudio recupera e recria, com igual capacidade ficcional, as figuras de António Nobre e Tiago Veiga. O primeiro, conforme veremos, habita diversas categorias textuais do romancista português, do ensaio ao teatro, da fotobiografia ao conto. Já o segundo constitui um dos grandes e expressivos resultados de pesquisa biográficoromanesca, em Tiago Veiga, uma biografia (2011).

Para as nossas reflexões, nos centraremos no conto "António Nobre e Alberto de Oliveira", texto que encerra uma sequência cronológica de doze histórias de amor, inserido na obra Triunfo do amor português (2004). Envolvendo tramas de diferentes épocas, partindo da Idade Média, passando 
pelos séculos sucessivos, sem esquecer a trágica trajetória de D. Pedro e D. Inês de Castro, ou o "fogo que arde sem se ver" (CAMÕES, 1994, p. 101) sentido por Camões e a Infanta D. Maria, ou, ainda, os encontros e desencontros de Camilo Castelo Branco e Ana Plácido, a coletânea aporta na passagem dos séculos XIX a XX, com a amizade amorosa entre António Nobre e Alberto de Oliveira.

Ainda que a ordem regida pelo eixo temporal fique evidente na sua organização, gostamos de pensar que o desfecho da sequência destas histórias, celebrado com uma narrativa de nítida afetividade homoerótica, consagra não apenas as múltiplas formas de amor e do amar, mas também a maneira como elas se consolidam, sobretudo, porque o último conto reivindica, no espaço das ocorrências amorosas dentro da cultura portuguesa, o respeito pela diferença, pelo direito a usufruir até às ultimas consequências de um sentimento que não estabelece regras impositivas ou hierarquias imperativas. Ama-se. E isto é o suficiente para colocar os protagonistas oitocentistas dentro de um elenco que afirma o triunfo do amor português.

Só esta articulação na disposição da trama de "António Nobre e Alberto de Oliveira" e a sua inserção dentro de uma obra que exalta o amor e elege protagonistas tão 
reconhecidos dentro do cenário cultural, como Luís de Camões, Mariana Alcoforado, Tomás António Gonzaga, Conde de Marialva e Camilo Castelo Branco, dentre outros, já forneceriam subsídios suficientes para interrogar sobre aquela ausência do nome de Mário Cláudio dentro de estudos que pretendem estudar a condição homossexual na literatura portuguesa contemporânea, conforme mencionamos no início deste estudo ${ }^{1}$.

Ainda que o título do conto em análise remeta o leitor a procedimentos já empregados pelo autor em outros textos (vide, por exemplo, Amadeo, 1984; Guilhermina, 1986; e Rosa, 1988; ou, mais recentemente, Tiago Veiga, 2011), é preciso já esclarecer que não se trata de projetos semelhantes. Basta observar a própria extensão do gênero textual empregado para se perceber que, dadas as condições estruturais, o título da obra de 2004 não poderia abarcar todos os instrumentos necessários para a concretização de uma

\footnotetext{
1 Sabemos que esta obra de Mário Cláudio foi escrita um ano depois da publicação de Fractura, de Eduardo Pitta (2003). No entanto, causa-nos um certo estranhamento verificar o silêncio do ensaísta sobre o nome do autor de Ursamaior no extenso elenco enumerado por ele, já que Mário Cláudio possuía obras, na altura da publicação do referido estudo, ligadas ao tema em questão. Outro dado que desperta a curiosidade do leitor atento é o de que, mesmo depois de 2003, Eduardo Pitta (2007), nas suas crônicas e críticas jornalísticas, produzidas posteriormente a Triunfo do amor português (2004), refere-se a artistas e escritores homossexuais (Al Berto, Alan Hollinghurst, Daniel Balderston, James Saslow, Luis Antonio de Villena, Manuel de Freitas, Robert Giard, dentre outros) e a outros exogenamente envolvidos com a questão da homossexualidade, mas jamais cita abertamente Mário Cláudio. Questões políticas? Gosto literário? Mal entendidos pessoais? Não cabe, aqui, interrogar ou levantar conjecturas, mas, fato é que esta ausência cria um vácuo significativo num ensaísmo que poderia não pecar por uma ausência sentida e significativa. Quem sai perdendo com isto? Com certeza, os leitores.
} 
biografia romanceada. No entanto, também são perceptíveis algumas incidências sobre tal categoria, visto que o conto apresenta uma linearidade na sequência temporal, revelando uma preocupação de ordenação dos fatos, dos tempos em que estes se sucedem, das ocorrências mais significativas na trajetória dos agentes principais da trama.

Assim, dos 21 anos de António Nobre (1888), época em que ingressa na Universidade de Coimbra, até a sua morte, em 1900, o poeta aparece recuperado com uma perspectiva que sai de um plano mais amplo e vai, gradativamente, diminuindo, quase como num recurso cinematográfico, até atingir a imagem física do rapaz recém-chegado à cidade universitária e o seu companheiro. Com este procedimento narrativo, surgem, primeiramente, Coimbra, "a velha Cidade académica", com seu "amontoado de casas brancas, a cujos pés corre o Mondego" (CLAUDIO, 2005, p. 235), depois a Universidade com seus "lentes macambúzios e bolorentos" (CLAUDIO, 2005, p. 235), seus "estudantes boçais e cruéis" (CLAUDIO, 2005, p. 236), que recusam ostensivamente a presença de António Nobre, porque não conseguem compreender a grandeza do escritor em semente que já nele se encontra, e, por fim, o próprio poeta que, diante de um cenário decadente, surge como uma espécie de astro 
brilhante, capaz de afogar as tonalidades medíocres que encontra pelo caminho:

Não o acolhem os membros dos dois corpos dominantes, o que deseja ensinar e o que resiste a aprender, como príncipe encantado, a quem basta proferir uma palavra de oiro para que se lhe abram as portas do aplauso que lhe couber na fantasia. [...] Apetecem ao novo escolar as longas tiras de oceano azul, orladas pela espuma das ondas, as quais ainda há pouco o extasiaram nas férias familiares de Leça da Palmeira, e o convívio das menininhas que, quando o não idolatram, Ihe deixam o espaço adequado à fagueira sobrevivência de um impossível amor, elemento indispensável à maturação do sofrimento do poeta que de génio se prefigura. (CLAUDIO, 2005, p. 236 )

Já nas linhas iniciais, não esconde o narrador a natureza do amor que envolve os protagonistas da história. António Nobre surge descrito como um jovem ligado à natureza e à paisagem oceânica do Norte e convivente com as raparigas que o idolatram e chegam a alimentar por ele o sonho de uma relação afetiva, sublinhada como um "impossível amor". Ambígua na sua disposição, a expressão consciente do narrador aponta para duas possibilidades na representação do amor que parte do e converge para o poeta. De um lado, a impossibilidade afetiva entre uma das jovens e o autor do Só, 
pela simples razão de que o elemento feminino não o motiva a uma concretização física, dado, aliás, confirmado mais à frente pelo próprio narrador. De outro, sem especificar o destinatário do sentimento do poeta (se mulher ou homem), é a impossibilidade de realização plena e absoluta que marca a trajetória do artista. Impedimento, aliás, compreendido, não só pela essência do isolamento a que a personagem se encontra vaticinada, mas também pela natureza do amor que parece mover os anseios e as expectativas da personagem.

Talvez, por isso, na reconstrução do contexto históricocultural, o narrador move-se despudoradamente diante de cenas de rejeição e de incompreensão diante da diferença, daquilo que não se enquadra em moldes préconcebidos, procurando mesmo, a partir da inaceitabilidade da personagem dentro de uma ordem social marcada por uma forte homossociabilidade, desvelar não só os traços psicológicos, demarcadores de um espírito fadado ao desterro e à solidão, mas também os físicos, aqueles que retiram a personagem de nichos indumentários e comportamentais, lugares-comuns esperados pela figuração masculinista da época, de nítido lastro vitoriano:

A arrogância que adopta António Nobre, a fim de fazer face ao meio que, se o aceita por sua aparente excentricidade, o recusa por sua determinação canseirosa 
em se tornar notado, é um fardo que, já o prevê, terá de o arrastar por longos tempos, se não quiser cair na despersonalização aniquilante. Traça a capa como quem amortalha um cadáver, não se coíbe de insultar de tolos e de ignorantes tutti quanti, isola-se na resolução de admitir apenas quem se achar disposto a cantar-lhe loas, tudo enquanto escreve os versos que utiliza como metáfora viva, exclusivamente redentora, de um inatingível castelo, construído de papel e tinta. Aplicar-lheão os vários nomes que os dicionários não registam, rindo dele, conforme os temperamentos, à socapa ou de caras, e à medida que um punhado de colegas dispersos, desses que uma qualquer razão de singularidade reduz à ansiosa busca de um luzeiro, o procura, o abriga, transformando-o no guia que se elege na perpétua vontade de o suplantar, ou de o demitir. (CLAUDIO, 2005, p. 236)

Interessante observar que, na reconstrução do contexto histórico-cultural, o narrador revela as cenas de rejeição, de recusa e de incompreensão diante da diferença, da ex-centricidade, daquilo que não se enquadra em moldes preconcebidos e determinantes de um centro social privilegiado e segregador. Como bem sublinha Irene Vaquinhas, o cenário onde António Nobre desponta é exatamente aquele dominado pelas "regras impostas pela cultura da aparência, a qual se 
manifesta, a nível individual, no cuidado com o corpo e na submissão à moda" (2011, p. 10). Na contracorrente destas expectativas, António Nobre emerge como uma personagem destoante destes estereótipos oitocentistas, destes lugares-comuns impostos por um código de conduta incapaz de o satisfazer enquanto artista e ser humano. Por conta desta conduta comportamental insatisfeita, acaba por receber em troca o desdém, o deboche e a alcunha imprecatória que o próprio narrador se recusa a nomear, daí a reação do poeta em isolar-se desta malta superficial, no seu "inatingível catelo, feito de papel e tinta", num gesto singular de resistência às normatividades.

A sua arrogância inicial, ou aquele "desdém natural dos príncipes" como afirmará Raul Brandão (2000, p. 122), a sua impaciência diante da mediocridade expressa dos seus convivas e o seu isolamento em virtude da intolerância experienciada são formas de reação de um poeta que, na contracorrente de regras impostas, faz versos expressando a sua singularidade e a sua inadaptabilidade num cenário hostil e pouco compreensivo com a diferença de sua natureza como homem e como artista. Daí o surgimento, como uma espécie de bálsamo, dos componentes do grupo da Boémia Nova, que recebem o escritor não apenas como 
mais um membro da revista, mas, sobretudo, como mais um dentre os artistas "ansiosos por um luzeiro", ou seja, dentre aqueles que sentiram o lancinante poder da segregação, que os colocando do lado de fora de um centro, ainda que pobre, superficial, indisposto e incapaz de compreender e aceitar estas personagens do universo literário.

Deste grupo, como era de se esperar, surge o par do poeta que, com ele, irá tecer o mote das linhas deste amor. Vítima também das estroinices dos seus pares acadêmicos, Alberto de Oliveira emerge do cenário oitocentista recuperado pelo narrador como uma fonte rica de recursos para a sua recriação nas tábulas ficcionais:

Quanto ao segundo rapaz trata-se de um pequeno prodígio, dando entrada com catorze primaveras, tão-só na mesma Faculdade de Direito que o vate do Norte frequenta, o que desencadeia uma modalidade distinta de chacota, por parte da malta, e que é a que nada coroa, ficando-se pela pura verificação de um fenómeno natural. Chama-se Alberto de Oliveira, e as fotografias revelamno por essa altura muito sério, mais próximo de um seminarista arrependido que de um decadente de pena fácil, tendo acabado de largar uma estudiosa infância, de cadernos impecavelmente mantidos, com a única distracção pelo meio de ir às vidraças da janela, e a intervalos, na tentativa de apanhar 
de um golpe as moscas restolhantes, estonteadas pelos calores do princípio do Verão. Se conhecerem-se, e amaremse, não foi como é patente obra de um momento, atribua-se à época, tão pronta a conceder o que nega, e a descobrir o que escamoteia, a diuturnidade do afecto, votado a labirintos onde se entra, e donde se sai, quando não se está certo, nem seguro, de pretender alcançar o centro. (CLAUDIO, 2005, p. 237-238)

O jogo de representação das personagens escolhido pelo narrador desvela uma sintonia com os tipos de processos imaginativos de criação, sublinhados por Ítalo Calvino na sua lição sobre a visibilidade. Ao defender este aspecto como uma das marcas fundamentais da ficção do século XXI, o ensaísta italiano acentua duas categorias imprescindíveis: uma "que parte da palavra e chega à imagem visual" (2006, p. 103) e outra "que parte da imagem visual e chega à expressão verbal" (2006, p. 103). Interessante observar que os dois processos encontram-se neste conto de Mário Cláudio. Se a visualização inicial de Coimbra, da Universidade, dos corredores da Faculdade de Direito, dos colegas de sala de aula e de António Nobre, emana do texto com aquele efeito de sermos "levados a ver a cena como se se desenrolasse diante dos nossos olhos, ou pelo menos fragmentos e pormenores da cena que emergem do indistinto" (CALVINO, 
2006, p. 103), a composição de Alberto de Oliveira desvela os procedimentos de criação utilizados. Não se trata, agora, apenas de dar corpo a figuras biograficamente instituídas, valendo-se de uma imaginação abstrata das personagens, mas de trazer-Ihes uma outra vida, pela plasticidade da matéria verbal e ficcional, a partir de fontes fotográficas, por onde, também, como nos processos fílmicos, o movimento criador é acionado por um "cinema mental" (CALVINO, 2006, p. 103). No caso do texto de Mário Cláudio, é o próprio narrador que assume esta atuação, ao retirar das imagens fotográficas um Alberto de Oliveira, como ficou dito, "muito sério, mais próximo de um seminarista arrependido que de um decadente de pena fácil” (2005, p. 237-238), e, lançando mão daquele mesmo recurso da visibilidade calviniana, ao reconduzir a sua trajetória fora dos parâmetros escamoteadores esperados pela época dos artistas.

Não deixa, portanto, de se valer o narrador desta pedagogia da imaginação para recriar as suas personagens, os cenários, os diferentes grupos que se formam à volta dos dois artistas, os espaços e o tempo. Nesta confluência de representações múltiplas, o projeto de criação de Mário Cláudio encontra consonância com a visibilidade defendida por Ítalo Calvino, no sentido de que, em "António Nobre 
e Alberto de Oliveira", os instrumentos estruturadores do texto permitem que "as imagens se cristalizem numa forma bem definida, memorável e "icástica'" (CALVINO, 2006, p. 112). Afinal, não são as duas personagens retiradas de um cenário possível e recriadas dentro de um universo habitável, como aqueles "mundos mobilados", de que nos fala Umberto Eco (2004, p. 218-219)? Não são as personagens circundantes e os diferentes ambientes, componentes de uma paisagem cristalizada e bem definida aos olhos do narrador e, consequentemente, do leitor?

Assim sendo, a proposta de visibilidade instaurada no texto de Mário Cláudio tem a ver com aquela intuição pedagógica de afinidade de artistas, de escolha íntima de obras e títulos que cada autor guarda consigo. Daí, talvez, a compreensão da incidência e da insistência da presença de António Nobre no universo imaginário e criador do autor de Triunfo do amor português. Das malhas do teatro, da fotobiografia, do ensaio e da ficção, o poeta do Só confirma-se como referência multímoda e essencial do autor contemporâneo, capaz de Ihe proporcionar matéria suficiente para as suas inventivas realizações. Tem razão, portanto, Maria Alzira Seixo, quando afirma ser Mário Cláudio um leitor crítico de António Nobre que "lê os textos, 
as figurações subjetivas, os enunciados personalizados da comunicação, as impressões escritas e as sinalizações e mostras do corpo deste poeta que aborda" (2004, p. 10).

Se, na fotobiografia, as revisitações aos textos de contemporâneos de António Nobre constituem paradas obrigatórias para ampliar a visibilidade sobre o contexto oitocentista do poeta, sobre sua obra e sua trajetória, nesta ficção curta, as mesmas figurações registradas nas memórias de Teixeira-Gomes (1960) e Raul Brandão (2000) reaparecem intertextualmente como marcas fundamentais para se apreender a natureza da personagem, das suas relações com figuras do sexo oposto e dos afetos que a unem ao jovem Alberto de Oliveira. Este exercício de revisitação ao século XIX, pela escrita nobreana, pelos afetos entre os dois amigos e pelos pensamentos dos escritores oitocentistas contribuem para a construção de uma visibilidade sobre o poeta do Só, bem como para a consolidação daquilo que Maria Alzira Seixo muito acertadamente irá definir como uma "poética crítica" (2004, p. 11), ou seja, a "escrita de um escritor que dialoga com outra escrita em termos reflexivos" (SEIXO, 2004, p. 11).

Um dos pontos mais evidentes desta necessidade de reflexão sobre a imagem do escritor finissecular reside na 
exposição da excentricidade e do gosto pelo incomum, pelo singular e pela diferença que aparece como a marca mais visível do poeta aos olhos do narrador. Mesmo mantendo um certo distanciamento heterodiegético, este não se furta a registrar, recriar e refletir sobre a homoafetividade entre os dois jovens portugueses, marca singular de uma relação que o século XIX não estava preparado para digerir. De acordo com o narrador:

Entre António e Alberto formase a invisível corrente, através da qual transitam crípticas imagens de cumplicidade, e de ternura, que os restantes em absoluto incompreendem, se bem que as deduzam dessa espécie de intensa perturbação que impregna o ar dos sótãos. Se no arranjo dos manuscritos destinados à tipografia, ou no manuseamento das Fêtes Galantes, de Verlaine, se roçam os dedos daqueles dois, é para se retirarem em asfixiada apreensão, menos de que se desvende o segredo que não ousam denunciar do que se explicite o discurso dos gestos. (CLAUDIO, 2005, p. 238)

De cumplicidade e de ternura, portanto, constitui-se a relação entre as personagens, a ponto de ambas se irem "imitando nos tiques do vestuário, e na linha dos maneirismos" (CLAUDIO, 2005, p. 239), dos seus gostos se misturarem e dos planos e objetivos convergirem para um “inquebrantável 
pacto de sangue que enfrente o fatalismo do casamento" (CLAUDIO, 2005, p. 239). Não restam dúvidas, portanto, de que o amor aqui retratado não é o Ágape, não é aquele que se compraz na conivência da caritas ou de uma aproximação despreocupada e desvinculada do contato físico, mas trata-se de Eros, filho de Afrodite Urânia, exatamente aquela gerada do encontro entre as águas do mar e os órgãos sexuais de Urano, cortados por Crono (GRIMAL, 1976; MARTIN, 1995).

E esta invocação à deusa do amor numa dimensão uranista (no sentido mitológico do termo) não se trata de uma novidade, conforme assinala Maria Theresa Abelha Alves Marques (1991), em sua leitura da obra Olga e Cláudio. No lugar, porém, de dois homens das belas artes (um pintor na Itália e um poeta em Portugal) afastados pelo distanciamento geográfico e sem qualquer indicativo de uma separação geracional ou informação sobre suas faixas de idade, pode-se inferir que, na recriação deste par homoerótico - António Nobre e Alberto de Oliveira -, Mário Cláudio vai buscar também nas tradições clássicas a fonte para a sua releitura da relação afetiva existente entre um homem mais velho e um adolescente. Ainda que não se possa afirmar que a personagem de António Nobre preencha totalmente todas as prerrogativas de um mestre, 
de um tutor, de um orientador, conforme delineadas nas formas como a homossexualidade masculina era vivida nas relações gregas, vale sublinhar que, quando se conhecem, o poeta conta com 21 anos e Alberto de Oliveira, ingressante na Universidade de Coimbra, com 14 anos. Ou seja, as duas personagens são separadas por sete anos apenas.

Esta informação precisa do narrador não deixa de se configurar como uma espécie de pista para entender a natureza da afetividade que entre eles se estabelece também dentro do foro pedagógico. Afinal, é com António Nobre que Alberto de Oliveira aparece como leitor da poesia oitocentista finissecular no "manuseamento das Fêtes Galantes, de Verlaine" (CLAUDIO, 2005, p. 238) e, em seguida, como uma espécie de espelho na repetição incontida de gestos e "maneirismos, por um inconsciente afã de por em comum o que corresponde à pertença individual" (CLAUDIO, 2005, p. 239). Também pelas mãos do poeta do Só, o amigo mais jovem recebe "num poema lindo, o título de 'condezinho Tolstoi'” (CLAUDIO, 2005, p. 239) e os indicativos da consolidação de um sentimento que, "não sendo amizade, só com a mais elevada essência afectiva, perigosa de se nomear, se deparará em condições de coincidir" (CLAUDIO, 2005, p. 239-240). A sintonia e a 
intimidade entre eles crescem, na medida em que ambos se transferem, numa nítida interferência do agente mais velho deste singular casal, para Leça da Palmeira, espécie de panegírico da homoafetividade que entre eles se estabelece:

Quando cuida António Nobre de viver sem vigilâncias nocivas, nem escolásticos impedimentos, a amizade que entre ele e Alberto de Oliveira foi gloriosamente crescendo, é em Leça da Palmeira que pensa, não como cenário do desenrolar de um drama idílico apenas, mas como substância que deverão dividir em fracções iguais dois poetas, praticando do amor de um Portugal a que os pintores não são capazes de aceder. (CLAUDIO, 2005, p. 240)

De forma muito subtil, o narrador marioclaudiano vai tecendo as gradações de uma relação que não abandona o lastro pedagógico, no sentido de que, guiados pela mão de um agente mais velho, os dois jovens vão aprendendo os gostos, as manias, os trejeitos, os hábitos de leitura e as particularidades de cada um, sem menosprezar o que de experiência, sobretudo a nível intelectual, António Nobre, o responsável pela pedagogia homoafetiva que entre eles se estabelece, pode oferecer a Alberto de Oliveira, e com ele também aprender novas formas de dizer amor, incluindo a expressa pela sua poesia, com títulos e epítetos que evocam o amigo mais novo. 
Mesmo não perfilando uma intimidade sentimental com os mesmos e idênticos traços dos enlaces homossexuais da tradição legada pelos gregos, Mário Cláudio parece investir naquela possibilidade de perceber uma "vincada feição pedagógica, sobretudo ao nível da mundividência" (LOURENÇO, 2009, p. 307), na relação entre António Nobre e Alberto de Oliveira. O fato de não entrar em detalhes explícitos sobre o que entre eles ocorre nos espaços de intimidade, tais como a casa em Leça da Palmeira ou na residência em Paris, e a sua declarada opção em sugerir e indicar certos comportamentos e abordagens indicativas de uma ligação homoerótica entre os dois agentes parecem constituir fortes indicativos de um procedimento de leitura que não se compraz na vulgaridade ou na promiscuidade no momento de devassar o foro privado deste casal. Antes, tal como experienciado nos envolvimentos afetivos entre os gregos antigos e clássicos, na lúcida explicação de Frederico Lourenço (2009, p. 307), também entre António Nobre e Alberto de Oliveira não deixa de transparecer "um sentimento de pudor e até de castidade, por respeito para com a integridade física do amado, respeito esse inspirado pela sua condição social" (LOURENÇO, 2009, p. 307), intelectual e artística. Não será gratuito, portanto, o fato de o narrador explicar que, entre eles, se estabelece um elo que 
vai do "jogo do mais aliciante magnetismo" (CLAUDIO, 2005, p. 238) a uma “invisível corrente" (CLAUDIO, 2005, p. 238 ), marcada pela cumplicidade, pela intimidade e pela sintonia de ideias estéticas e gostos pessoais.

Como no par formado pelas personagens humanas de Olga e Cláudio, por exemplo, também aqui as personagens vivenciam a experiência da arte e dela se valem para partilhar um amor mútuo, mas ainda não explícito, não revelado, apesar das investidas e das atitudes emancipadas de Alberto de Oliveira em expressar os seus sentimentos ao companheiro. Poeta do recolhimento, da solidão e do sofrimento, a personagem António Nobre recua diante da possibilidade de revelar um amor que ousa dizer o seu nome. Daí a sua aparição como um interlocutor marcado por uma "visível frieza" (CLAUDIO, 2005, p. 238), e nela se acobertar "por tudo sofrer muito mais tumultuosamente do que quem o desafia" (CLAUDIO, 2005, p. 238), daí a relação entre eles ser marcada por uma "exclusiva prática de esconde-esconde" (CLAUDIO, 2005, p. 238) e por um medo velado ao perceber, paulatinamente, o "progresso daquilo que, não sendo amizade, só com a mais elevada essência afectiva, perigosa de se nomear, se deparará em condições de coincidir" (CLAUDIO, 2005, p. 239-240). 
Se não for o medo, decerto poderá ser a culpa de nutrir um sentimento proibido e condenado pela sua época o que move as reações da personagem. Como lembra Agustina Bessa-Luís, a respeito de Triunfo do amor português, "o amor se previne com a culpa para ser agente de mudanças" (2005, p. 14), seja ela no plano individual dos agentes participantes deste sentimento arrebatador e aniquilador, seja no plano coletivo que leva os amantes a atitudes extremadas (ou não), mas quase sempre vivenciadas em conjunção. Assim parece ser o sentimento movente que leva os dois jovens de Coimbra a Leça da Palmeira, pelo menos, dentro da perspectiva de António Nobre que vê naquela paisagem a esperança de buscar "a salvação de sua carne e o perdão de suas culpas" (CLAUDIO, 2005, p. 240).

No entanto, também em Leça ambos passam por outra experiência coletiva, não mais a do olhar repressor do amor que não podia dizer o seu nome, alvo do acadêmico "rebanho sombrio" (CLAUDIO, 2005, p. 239) de Coimbra e do seu "apiedado desprezo" (CLAUDIO, 2005, p. 239). $\mathrm{Na}$ casinha de Leça da Palmeira, as personagens causam um "alarme divertido" no "ramerrão balnear dos leceiros que não mais haverão de se esquecer" (CLAUDIO, 2005, p. 242), provocando a curiosidade alheia, a ponto mesmo de 
marcarem toda a convivência social da cidade. E não será à toa, como bem situa o narrador, que a alcunha da Rua dos Dois Amigos constitui uma referência direta ao convívio dos dois jovens naquela morada.

Conforme sublinhamos, não pode ser um amor edênico ou agápico o que aqui se narra, mas um amor filho de Afrodite Urânia, a ponto de despertar na voz narrativa um desejo indiscreto de perscrutar o cotidiano de António e Alberto. Evidencia-se, portanto, entre os dois amigos, um sentimento que ultrapassa a amizade intocável e sem possibilidade de investidas e aproximações. Se assim fosse, não seria esta a imagem carregada daquela visibilidade, daquela capacidade de criar figurações imaginárias a partir da articulação plástica da matéria verbal, como a que deixa entrever o narrador:

De leite quase exclusivamente é que se alimentam, e de pão muito alvo, tudo o que Ihes traz à imaginação, obcecada pelos topos da pureza, a imagem da lã da ovelha e da vela do moinho, da pétala da açucena imaculada e da asa do anjinho processional, com vista a que no outro branco, o dos lençóis que a mãe Ihes cedeu, e que cheiram a alfazema e a sabão de barrela, ousem deitar-se para o inefavel diálogo que não saberão se termina no sono sem sonhos, se no sonho inesperado a que não se assiste sono algum. (CLAUDIO, 2005, p. 242) 
Não nos parece gratuita a incidência da cor branca no cenário particular da casa dos jovens, no pão, no leite, espécie de elementos de uma outra eucaristia, onde a imaginação das personagens se desprende para pousar sobre outros "topos da pureza" (CLAUDIO, 2005, p. 242). É o mesmo branco, a cor que simboliza a pureza, a imaculabilidade, a junção de todas as cores e, consequentemente, de todos os sentimentos que as mesmas representam, que sai dos elementos físicos (a lã da ovelha, a vela do moinho e a flor) e, numa gradação mística, atinge a plenitude da sagração ao repousar sobre as asas de um pequeno anjo processional. Com este recurso, pensamos que Mário Cláudio não deixa que a trama resvale na permissividade ou na vulgaridade, simplesmente porque se invoca, aqui, um amor homoerótico. Ao contrário, ao convocar o cromatismo branco, consagra a homoafetividade que entre António e Alberto coexiste sob o signo da transparência e da diafaneidade (CHEVALIER; GHEERBRANT, 1991).

Pode-se inferir, ainda, que, na verdade, o elemento motivador das histórias que compõem Triunfo do amor português não se centraliza especificamente no elenco que denomina as personagens atuantes e os diferentes contextos em que elas se situam e fazem o sentimento brotar. Como o 
próprio título da coletânea parece sugerir, o amor também se constitui como um dos protagonistas destes contos. Neste sentido, ao lado de D. Pedro I e Da. Inês de Castro, de Luís de Camões e Da. Maria, de Camilo Castelo Branco e Ana Plácido, também há espaço para um amor que se destaca na sua diferença e triunfa de igual modo que os demais, o amor homoerótico presente na relação entre dois jovens, António Nobre e Alberto de Oliveira.

No caso específico do conto "António Nobre e Alberto de Oliveira", o sentimento amoroso entre as duas personagens está sujeito às mesmas etapas de qualquer outra relação afetiva. Tanto assim é que, depois do impacto do primeiro encontro em Coimbra, do deslumbramento do reconhecimento dos gênios e temperamentos, do idílio vivido no pacto das afinidades e do partilhar da mesma casa, desenrolam-se situações que marcarão definitivamente a relação dos dois sujeitos oitocentistas: o infortúnio causado pelas reprovações sucessivas na Faculdade de Direito, o desafogo na viagem de António a Paris, o desencanto diante de tonalidades diferentes nas correspondências trocadas, o ciúme de António ao perceber que Alberto pretere a sua companhia em favor da oferecida pelas mulheres da maison close, a decepção, o afastamento e, por fim, a separação 
definitiva pela doença e morte de António, não sem Alberto tentar reencontrar nos braços do amigo algum lastro do sentimento que, um dia, os uniu.

Nestes passos, em alguns momentos, o narrador, de maneira muito generosa, não se furta a dialogar com toda uma tradição que via na excentricidade do poeta traços incomuns de uma subjetividade ímpar, mas que, na sua dimensão ainda contaminada pelos estertores deterministas, se recusava a nomear. Um dos momentos em que este diálogo intertextual se processa encontra-se na ida do casal de jovens a uma casa de cortesãs, em Paris. Na trama criada por Mário Cláudio, a iniciativa da visita ao local parte do próprio Nobre, na tentativa de trazer Alberto de Oliveira para perto de si, em virtude do deslumbre que os sítios parisienses causam no recém-chegado de Portugal. De acordo com o narrador,

De noite é rumo a uma das decantadas maison closes que o andar os encaminha, e não constitui tolice aventar que prepararia Nobre a visita na inconsciente conviç̧ão de que o estímulo dos sentidos, perpetrado por aquilo que ele próprio denomina "carne trágica", Ihe devolverá um parceiro menos desconcentrado, mais entendedor das coisas do coração. Vem recebê-los uma madame vagarosa, deslocando-se de cabeça levantada, apoiando-se num bastão, e que os conduz, e através dos 
vasos de tuberosas, ao grande sofá capitonné onde se sentam as diversas meninas, baixando e repuxando as meias pretas, e com o sorriso descuidoso e magoado, acariciando-se umas às outras, e por entre o que parece ser uma nuvem de pó-de-arroz. Para que não tropece nos tamboretes disseminados, nem se atemorize dos cavalheiros que o miram desdenhosamente, bem necessário será que se socorra Oliveira da certeza de que se acha ali mesmo o seu anjo-da-guarda, e com a capa longuíssima que leva a que o confundam com um padre confessor de damas do Faubourg Saint-Honoré. Que virgindade irá ele perder gloriosamente, se tudo esgotou, os nervos e a vaidade, o medo e as certezas, na travessia do salão imenso onde as campânulas dos candeeiros se assemelham a globos oculares, extraídos por um maníaco dissecador, sobre o mármore de uma anatómica? (CLAUDIO, 2005, p. 247-248)

Ora, esta comodidade em perceber na personagem masculina a figura clerical de um confessor não deixa de corroborar aquela facilidade impeditiva destacada por Teixeira-Gomes no retrato que faz de António Nobre. Com a licença da ficção, Mário Cláudio recria a situação presenciada pelo autor de Regressos, nas ruas do Porto, dimensionandoas, agora, nas casas cortesãs parisienses, e não abrindo mão de uma mesma conveniência que passa também a dominar nas diferentes relações que o poeta estabelece com as jovens 
dos estabelecimentos. Como ocorrera em Portugal, a partir das páginas de Manuel Teixeira-Gomes, também em Paris, parecem todas elas tomar "muito a sério e respeitosamente, o António Nobre por padre, o que o lisonjeia e lhe facilita a resistência..." (1960, p. 161).

No conto em estudo, a situação repete-se não no sentido de que a personagem procura nos prazeres femininos a realização plena de um pacto de cumplicidade estabelecido entre os dois jovens, mas na expectativa que nutre António Nobre em desfazer o halo de magnetismo sedutor que o espaço parisiense acaba por exercer por Alberto de Oliveira. Daí que a ânsia do poeta seja exatamente a de reconquistar a concentração de Oliveira sobre si, para a sua "teia de inatingíveis ternuras" (CLAUDIO, 2005, p. 247). Na verdade, um misto de culpa por um sentimento interdito e a necessidade de trazer o companheiro de volta para o seu regaço parecem ser os princípios motivadores do poeta que, numa ambiguidade de comportamentos, não consegue esconder a natureza dos seus sentimentos, sobretudo quando percebe que Alberto de Oliveira sente-se completamente atraído pelos encantos de Paris, a ponto mesmo de se esquecer de sua companhia. Já aqui, a culpa possível e a atenção desejada dão lugar a uma cena de ciúmes que acaba por causar a ruptura entre os dois amantes: 
Pouco depois ficará o poeta até de madrugada, encolhido em seu canto, com o Eclesiastes à frente, e uma resma de papéis, calcada por uma caveira, aguardando o camarada, com quem se recusou a sair, tendo ajustado a máscara de vítima de sua extenuada paixão. Ao regressar o outro, dirigir-seIhe-á destrambelhadamente, e como se tivesse acordado de um sonho malfazejo, exigindo-lhe contas do dinheiro emprestado, ameaçando esbofeteálo, responsabilizando-o pelo gelo que se lhe apoderou dos ossos, tudo isto enquanto se planta o pequeno touriste, um pouco trémulo, chupando a cigarrilha murcha como esse ar que possuem os adolescentes, ao desvendar o que existe além das fronteiras de sua pátria, de se reputarem senhores deles próprios e do Universo total.

De um cúmulo de contínuos agravos, explorados até á exaustão pelo rapaz especial, deixado agora por Alberto de Oliveira absolutamente desamparado em Paris, começa a desenvolver-se o delírio de solitude, ou a psicose de abandono, de quem fundara, há que tempos!, seu reino de amores à beira-mar. [...] A metamorfose que sofrera Alberto, levando-o a conversar agora como futuro embaixador que se deseja, ao receber uma deputação de comerciantes que pretende sondá-lo, apoiada nos presentes de porcelana de Meissen com que o contempla, sobre as hipóteses de vender seus produtos em Portugal, 
essa metamorfose irremediavelmente o afasta, e para nunca mais se reabilitar, da postura de "figurinha gentil", perdida entre a multidão do cais de Lisboa, a acenar na despedida do amigo que o divinizava. (CLAUDIO, 2005, p. 248)

Toda a efabulação do desentendimento que entre os dois jovens eclode evidencia a natureza de sua afetividade amorosa e o quebrantamento resultante da percepção de António Nobre do desinteresse e da desconcentração do amigo mais novo diante das seduções e do magnetismo do cosmopolitismo parisiense. No lugar de se tornar o panegírico do amor entre Nobre e Oliveira, Paris torna-se o local de desencadeamento do ciúme e da ruptura. A passagem acima não deixa dúvidas do sentimento nutrido pelo poeta, sobretudo porque toda ela se coaduna com aquilo que Roland Barthes chama de "fazer uma cena", ou seja:

Quando dois sujeitos discutem de acordo com uma permuta regulamentada de réplicas e tendo em vista conseguir a "última palavra", estes dois sujeitos estão já casados: a cena é para eles o exercício de um direito, a prática de uma linguagem de que são coproprietários. (BARTHES, 2010, p. 64).

A aposta de Mário Cláudio na homossexualidade de António Nobre, poeta mais que reconhecido dentro do 
cânone da literatura portuguesa, não incide numa diminuição da importância e da qualidade da obra do poeta, muito pelo contrário, investe exatamente na multiplicidade de facetas que os versos do autor do Só podem deixar descobertas. Daí que a cena protagonizada por Nobre, o seu ciúme desmedido diante de Oliveira, seja exatamente uma forma de mostrar o grau de intimidade construído entre os dois, posto que, como na perspectiva barthesiana, esta "cena" efabulada por Mário Cláudio também não esteja desvinculada do "sentido doméstico do termo" (BARTHES, 2010, p. 64), ainda que não se possa falar exatamente em casamento, como nos moldes contemporâneos. Poder-se-ia mesmo conjecturar que, aos olhos do autor de versos como "E a Vida foi, e é assim, e não melhora. / Esforço inútil. Tudo é ilusão, / Quantos não cismam nisso mesmo a esta hora / Com uma taça, ou um punhal na mão!" (NOBRE, 2000, p. 316), soaria incompreensível e até inaceitável entender a união matrimonial entre duas pessoas do mesmo sexo como um ganho político, como ocorre na sociedade portuguesa atual.

Da irrupção do ciúme e da separação inevitável, as consequências são fatais para António Nobre. Divagando pelos "paisagísticos descampados da Europa" (CLAUDIO, 2005, p. 250) e sentindo os efeitos colaterais da doença que 
começa a tomar conta do seu corpo - "fiscalizando o escarro sanguinolento, desejando-o como emblema, execrando-o como sentença, em busca de um eu fragmentado que a espaços identifica com a noção de saúde" (CLAUDIO, 2005, p. 250) - o poeta não encontra outra saída a não ser o retorno. Desterrado da pátria e, agora, também do amor, resta-lhe o autoexílio em Leça da Palmeira, onde se recolhe num ensimesmamento sem retorno. Nas palavras do narrador, "na perpétua ausência de Alberto nenhuma silhueta humana parece povoar as areias" (CLAUDIO, 2005, p. 251), observase aquele estado de angústia de que nos fala Barthes, posto que o protagonista do conto muito se aproxima daquele "sujeito apaixonado [que] por esta ou aquela contingência, sente-se arrastado pelo medo de um perigo, de um mal, de um abandono, de uma alteração" (2010, p. 36).

E se este mal pode ser um indicativo daquela mesma doença, anunciada pela "portadora do bacilo de Kock" (CLAUDIO, 2005, p. 250) com a qual Nobre dialoga na viagem de retorno a Portugal, não se pode negar que a "angústia de amor" (BARTHES, 2010, p. 37), vivenciada pelo poeta, vem gradativamente gestada e é confirmada no estado de "receio de uma perda que se verificou, desde a origem do amor" (BARTHES, 2010, p. 37). 
Daí que, já aqui, caberia perguntar qual categoria de amor triunfa neste amor português entre António Nobre e Alberto de Oliveira, já que o afastamento entre os dois coloca o segundo num caminho de carreira política e comercial, e o primeiro num recolhimento trágico, onde os versos e as notas do seu Só passam a encontrar uma consonância ressoante. A princípio, poderia se pensar num amor fadado ao trágico e ao irrealizável, por se tratar de um amor entre dois homens. No entanto, também o incompreensível e o intangível não coabitam as efabulações amorosas dos outros casais (heterossexuais, diga-se de passagem) de Triunfo do amor português. Não se pode, portanto, reduzir a homoeroticidade a um único desfecho possível, mas cabe aqui entendê-lo na sua diferença e na sua articulação dentro de um universo de ocorrências amorosas. Como outros casais, este também, protagonizado por dois jovens artistas do final do século XIX, passa pelo processo de encantamento, união, partilha, decepção, separação e, por vezes, reencontro.

Tal é o que sucede quando António Nobre, consumido pela tuberculose, em casa do irmão, recebe a visita inesperada de Alberto de Oliveira. No percurso dos dois amigos, o narrador novamente opta pelo despudor da devassa da vida 
privada e discorre sobre o encontro final entre eles, com a preocupação de mostrar que, dentro do universo do amor português, também cabe o amor entre dois homens, entre duas pessoas do mesmo sexo, que se respeitam mutuamente e nutrem um sentimento genuíno e triunfante:

Está em Carreiros na Foz do Douro, e na residência do irmão, com os olhos mais escancarados do que nunca, absorvendo a cintilação do Atlântico, e de mãos juntas como quem espera que lhe venham ensinar uma oração, há séculos esquecida, e que confunde de vez em quando com um soneto rejeitado. Ao entrar Augusto, já o sol declinou, e suspenderam-se os espasmos que the provocam estremeções do esqueleto, e esplendidamente se sente, e como se tivesse acabado de nascer, concentrandose no labor da aranhazinha que, animada pelo calor, afanosamente segrega o fio. É Alberto quem em lugar do mano dedicado se aproxima, e pede-lhe António num murmúrio que o abrace, e ao achar-se apertado pelo companheiro de sempre, consente em que a cabeça se the descaia, de infinito êxtase, sobre o ombro daquele que jamais o traiu. (CLAUDIO, 2005, p. 251)

Gostamos de pensar que, no reencontro entre os dois jovens, na superação das distâncias, das separações e dos desentendimentos, se concretiza e se consolida o triunfo 
da efabulação deste amor homoerótico. E, ao contrário das relações afetivas dos tradicionais amores gregos, não parece haver espaço entre as duas personagens para uma hierarquia distanciadora, entre um tutor mais experimentado, ainda que, em termos intelectuais e estéticos, Nobre preencha tal condição, e um aprendiz inexperiente, ávido de suplantar o seu guia. Não parece ser uma ruptura do discípulo na tentativa de superar o seu mestre aquilo que reside nos sentimentos moventes de António Nobre e Alberto de Oliveira. Muito pelo contrário, posto que, no prazer do reencontro, no restabelecimento de um pacto momentaneamente esquecido e quase rasurado, as duas personagens traçam as linhas do último contato físico, ainda que, para além dele, o afastamento definitivo pela morte seja uma certeza irretorquível.

Caberá, portanto, ao narrador a tarefa de reconstruir as páginas desta história de amor num processo intertextual que evoca, em muitos momentos, a pena camiliana. Isto se dá, sobretudo, quando a voz narrativa revela o comando que exerce sobre as particularidades e as intimidades existentes na correspondência trocada entre eles:

Examinemos de que materiais se compõe a carta de ruptura, redigida pelo que durante uns três anos se unira a Oliveira, e que alcançarão esclarecer talvez os mais 
relapsos em aceitar o que adivinham, o que muito simplesmente preferem ignorar, não fôssemos nós muito mais fruto da imaginação praticada que do instinto irresistível. (CLAUDIO, 2005, p. 249; grifos nossos)

A iniciativa do narrador em examinar a correspondência, em vasculhar os meandros das frases expressas e em citar explicitamente aquilo que ele interpreta como os termos reveladores de uma homoafetividade, não deixa de pôr em relevo aquele exercício de visibilidade, sublinhado por Ítalo Calvino, no sentido de que estes recursos contribuem para a construção de uma espécie de iconologia nobreana dentro do universo ficcional marioclaudiano. Resgatar as falas de António Nobre, os seus versos e os caminhos de um possível trajeto pode ser entendido como uma operação de "extrair histórias da sucessão" (CALVINO, 2006, p. 114) de figuras do escritor oitocentista legadas pela tradição, mas que, definitivamente, parecem não saciar a curiosidade do Mário Cláudio-leitor. Assim sendo, na mesma dimensão estimulante de criação do ensaísta italiano, no conto em estudo, o poeta do Só pode ser lido como uma personagem pertencente a um elenco de "quadros famosos da história da arte" (CALVINO, 2006, p. 114) e da literatura portuguesa do século XIX, constituindo-se uma das figuras que sobre 
o autor português contemporâneo exerce uma sugestão motivadora de efabulação.

Ainda que a sua aposta na homossexualidade de António Nobre e na homoafetividade desenvolvida entre ele e Alberto de Oliveira resida na ocorrência de uma "poética crítica" (SEIXO, 2004, p. 11), não se pode perder de vista que tais efabulações constituem a medula de um constructo ficcional, matéria manipulável pela subjetividade autoral, portanto, sem um compromisso de veiculação factual, ainda que, por muitas vezes, deixe revelados no texto as referências e os caminhos intertextuais por onde tenha investido a sua leitura. Procedimento muito peculiar nos projetos ficcionais de Mário Cláudio, este "traçar na escrita a memória apagada pelo tempo" (CERDEIRA, 2000, p. 117), cujo encaminhamento inexorável vai "para um outro lugar, para um outro tempo, para uma outra história" (CERDEIRA, 2000, p. 117), na lúcida explicação de Teresa Cerdeira, também este António Nobre constitui-se um António Nobre escrito, nascido dos textos possíveis, reinventado pelos bordados da ficção. Se o poeta nortenho vem iluminando, desde sempre, a trajetória do autor contemporâneo, como o próprio Mário Cláudio irá afirmar (CLAUDIO, 2004, p. 51), não deixa de ser este conto uma maneira também de "melhor iluminar um percurso 
pretérito, o de António Nobre" (CLAUDIO, 2004, p. 51). A memória que inscreve o amor triunfante e emergente de sua relação com o jovem Alberto de Oliveira

como texto não é a que pretende o resgate da similitude com um eu passado, mas a invenção do eu que, da rasura do primeiro, do seu esquecimento necessário, abre espaço para a ficção que reinventa, transforma, traduz. (CERDEIRA, 2000, p. 117).

Ora, tal cotejamento realizado sobre a figura do poeta oitocentista concretiza-se textualmente, muitas vezes, a partir de uma articulação e de um diálogo com outras formas de contar, também caras ao criador do elenco sentimental de Triunfo do amor português.

Conhecedor íntimo das artimanhas narrativas de um Camilo Castelo Branco, por exemplo, no desfecho do conto em estudo, Mário Cláudio cria um narrador tecelão que vai deixando algumas pistas, ao longo da narrativa, dos procedimentos criadores adotados. Vale observar, aqui, que as cenas do amor trágico entre um Simão Botelho e uma Teresa de Albuquerque só foram possíveis de serem reinventados, não apenas pelas informações contidas nos documentos recuperados, mas, sobretudo, pelas cartas trocadas entre os dois, retiradas do mar, do corpo de uma Mariana suicida, 
logo, muito provavelmente comprometidas pela ação do desbotamento da tinta, causada pelas águas salgadas. Ora, em "António Nobre e Alberto de Oliveira", numa revisitação muito próxima deste recurso de preenchimento de lacunas e borrões, no sentido do que afirma Teresa Cerdeira (2000), todas as declarações de amor contidas nas cartas enviadas por Nobre e não respondidas por Alberto de Oliveira não poderão ter suas linhas parcialmente preenchidas, visto que, no conto de Mário Cláudio, todas elas serão definitivamente eliminadas pelo fogo, quando o antigo companheiro de Nobre

atirar-Ihe-á um fósforo naquele recando do relvado, e por debaixo da grande tília, indo sentar-se na cadeira de lona, e diante do tabuleiro de chá, a assistir à fogueira dos documentos que reputara de provavelmente inomináveis (CLÁUDIO, 2004, p. 253-254).

Consumidas pelo fogo e sem chance de serem recuperadas, caberá ao narrador retirar das cinzas e reconstruir integralmente "pela virtude do muito imaginar" (CAMÕES, 1994, p. 297) as palavras de amor não ditas, os gestos consumados pelo silêncio e a lição maior do triunfo deste amor que se realiza na diferença:

Os amores anónimos, e sem direito de cidadania, dos portugueses e das portuguesas, os quais não foram reis, nem rainhas, nem poetas, nem romancistas, 
consumar-se-iam naquele elevado lume, e até que de tanta ardência, explicada ou oculta, nada mais restasse do que um montinho de cinzas, alimento da perpétua radiância da cerejeira brava. (CLÁUDIO, 2004, , p. 254)

Evidencia-se, por fim, que, através "da análise das relações humanas e da correspondência" (SEIXO, 2004, p. 11), como bem sublinhará Maria Alzira Seixo, se alicerçará o afeto entre as personagens de António Nobre e Alberto de Oliveira. Mas, para além deles, o triunfo que se estabelece não é apenas o de dois homens, como sujeitos individuais, mas entre personagens-sujeitos do mesmo sexo, que ousam dizer o nome do seu amor, independentemente do tempo e do espaço, ganhando, assim, uma dimensão metonímica que elas próprias assumem, no tempo em que Ihes foi dado viver o seu sentimento. Daí a preocupação do narrador em frisar a condição do anonimato e da impossibilidade de reconhecimento público a que muitos portugueses e portuguesas, que também compartilham desta experiência amorosa, estão sujeitos. Do particular ao coletivo, o amor homoerótico entre os dois jovens consolida uma visibilidade não apenas no sentido estético da criação literária nos termos calvinianos, conforme salientamos, mas também no sentido político que a expressão adquiriu na 
contemporaneidade. A visibilidade articulada nas malhas da ficção é também aquela que os anônimos e os ex-cêntricos requerem na exigência e na emergência daquele "sagrado direito à diferença" (MELO, 1982, p. 58).

Ficção curta, centrada em dois lances brevemente biográficos, "António Nobre e Alberto de Oliveira", como outros títulos do escritor português contemporâneo, também "reinventa na escritura, com os farrapos e vestígios que o presente encena, uma história que não pretende resgatar a origem ou a ilusão referencial, mas aquela outra nascida da rasura inexorável de um tempo descontínuo que só enquanto ficção se recupera" (CERDEIRA, 2000, p. 124). Se "tudo é biografia" (SARAMAGO, 2006, p. 207), como enfatiza José Saramago, não menos estes dois sujeitos oitocentistas e o sentimento que entre eles aflora. Não deixa de ser, portanto, este conto uma espécie de "biografia da memória" (Apud MATOS, 2004, p. 76) do sentimento homoafetivo que entre as duas personagens pode ter existido. Triunfo de um amor singular, alicerçado na capacidade de compreender as diferenças, ainda que o tempo teime em negar a sua potencialidade, estas criaturas de Mário Claudio reinventam uma outra forma do amor que ousa dizer o seu nome, ainda que, muitas vezes, este fique calado no íntimo dos seus 
agentes. Se o terá sido na factualidade, pouco importa, afinal, conforme ensina-nos Ítalo Calvino, não "há coisas que só a literatura com os seus meios específicos pode dar-nos" (2006, p. 12), sobretudo, na sua capacidade de efabulação? O Triunfo do amor (homoerótico) português, entre poeta (sem esquecer outros personagens, como os pintores marioclaudianos), certamente, é uma delas.

\section{REFERÊNCIAS}

ARNAULT, Ana Paula. Post-modernismo no romance português contemporâneo. Fios de Ariadne, máscaras de Proteu. Coimbra: Almedina, 2002.

BARTHES, Roland. Fragmentos de um discurso amoroso. Trad.: Isabel Pascoal. Lisboa: Edições 70, 2010.

BRANDÃO, Raul. Memórias (Tomo III). Vale de Josafat. Edição de José Carlos Seabra Pereira. Lisboa: Relógio d'Água, 2000.

CALVINO, Ítalo. Seis propostas para o próximo milénio (Lições americanas). 5ed. Trad.: José Colaço Barreiros. Lisboa: Teorema, 2006.

CAMÕES, Luís de. Lírica Completa - II. Sonetos. 2ed. Prefácio e notas de Maria de Lourdes Saraiva. Lisboa: Imprensa Nacional - Casa da Moeda, 1994.

CERDEIRA, Teresa Cristina. $O$ avesso do bordado. Ensaios de literatura. Lisboa: Caminho, 2000.

CHEVALIER, Jean; GHEERBRANT, Alain. Dicionário de símbolos. 4ed. Trad.: Vera da Costa e Silva, Raul de Sá Barbosa, Angela Melim e Lúcia Melim. Rio de Janeiro: José Olympio, 1991.

CLAUDIO, Mário. Páginas nobrianas. Porto: Caixotim, 2004. . Triunfo do amor português. 2ed. Lisboa: Dom Quixote, 2005. 
ECO, Umberto. Os limites da interpretação. 2ed. Trad.: José Colaço Barreiros. Lisboa: DIFEL, 2004.

FERREIRA, Vergílio. "Literatura contemporânea - uma convergência em questão". In: Espaço do invisível - IV. Lisboa: Imprensa Nacional - Casa da Moeda, 1987, p. 129-133.

FURTADO-BRUM, Maria Ângela Azevedo. A Trilogia da Mão ou a biografia impura. Ponta Delgada: Universidade dos Açores, 1997. Dissertação de Mestrado em Cultura e Literatura Portuguesas.

GRIMAL, Pierre. Dictionnaire de la mythologie grecque et romaine. 5ed. Paris: Presses Universitaires de France, 1976.

HUTCHEON, Linda. Poética do pós-modernismo. História, teoria, ficção. Trad.: Ricardo Cruz. Rio de Janeiro: Imago, 1991.

LOURENÇO, Frederico. "Homossexualidade masculina e cultura grega". In: RAMOS, José Augusto; FIALHO, Maria do Céu; RODRIGUES, Nuno Simões (Coord.). A sexualidade no mundo antigo. Coimbra: Centro de Estudos Clássicos e Humanísticos, 2009, p. 305-312.

MARQUES, Maria Theresa Abelha Alves. "Olga e Cláudio: um encomion a Eros". In: Letras \& Letras. n.50, 03 de julho de 1991, p. 11-12.

MARTIN, René (Dir.). Dicionário cultural da mitologia greco-romana. Trad.: Fátima Leal Gaspar e Carlos Gaspar. Lisboa: Dom Quixote, 1995.

MATOS, Joaquim. Mário Cláudio: ficção e ideário. Porto: Caixotim, 2004. MELO, Guilherme de. Ser homossexual em Portugal. Lisboa: Relógio d'Água, 1982.

MOMIGLIANO, Arnaldo. Les origines de la biographie en Grèce Ancienne. Strasbourg: Circé, 1971.

NOBRE, António. Poesia Completa. Prefácio de Mário Cláudio. Lisboa: Dom Quixote, 2000.

PITTA, Eduardo. Fractura. A condição homossexual na literatura portuguesa contemporânea. Coimbra: Angelus Novus, 2003. . Intriga em família. Vila Nova de Famalicão: Edições Quasi, 2007. 
REAL, Miguel. O romance português contemporâneo 1950-2010. Lisboa: Caminho, 2012.

REIS, Carlos (Org.). História crítica da literatura portuguesa. Do NeoRealismo ao Post-Modernismo. Lisboa/São Paulo: Editorial Verbo, 2005.

REIS, Carlos; LOPES, Ana Cristina M. Dicionário de Narratologia. Coimbra: Almedina, 1987.

ROCHA, Clara. "Fiç̧ão dos anos 80". In: LOPES, Óscar; MARINHO, Maria de Fátima (dir.). História da Literatura Portuguesa. v.7. As correntes contemporâneas. Lisboa: Alfa, 2002, p. 463-486.

SARAMAGO, José. Manual de pintura e caligrafia. 6ed. Lisboa: Caminho, 2006.

SEIXO, Maria Alzira. "O olhar do autor". In: CLAUDIO, Mário. Páginas Nobreanas. Porto: Caixotim, 2004. p. 4-18.

. Outros erros. Ensaios de literatura. Porto: Edições ASA, 2001.

TEIXEIRA-GOMES, Manuel. Regressos. 3ed. Lisboa: Portugália Editora, 1960.

VAQUINHAS, Irene. "A família, essa 'pátria em miniatura'". In: História da vida privada em Portugal 3. A época contemporânea. Direção: José Mattoso. Coordenação: Irene Vaquinhas. Lisboa: Círculo de Leitores, 2011. p. 118-151.

Jorge Vicente Valentim é Professor Adjunto de Literaturas de Língua Portuguesa (Sub-áreas: Literatura Portuguesa e Literaturas Africanas de Língua Portuguesa) do Departamento de Letras da UFSCar. Vice-Coordenador do Programa de Pós-Graduação em Estudos de Literatura (PPGLit/UFSCar). Este trabalho constitui resultado parcial de pesquisa, realizada com Bolsa CAPES, de Pós-Doutorado Sênior, em 2013, na Universidade do Porto, sob a supervisão da Profa. Doutora Isabel Pires de Lima. 